\title{
Globalization Theory: Lessons from the Exportation of McDonaldization and the New Means of Consumption
}

\author{
George Ritzer and Elizabeth L. Malone
}

Recent dramatic increases in the transnational flows of capital, people, goods, information, and culture have transformed the world. The consequences of these far-reaching economic, political, demographic, and cultural changes have elicited increasing political and civic concern over globalization, as evidenced in 1999 in the mass protests against the World Trade Organization in Seattle and in the spring of 2000 against the World Bank and International Monetary Fund in Washington, D.C. Globalization theory, which seeks to construct theoretical models to address these realities, emerged both from the social changes that it seeks to explain and internal developments in social theory, most notably as a reaction to earlier perspectives such as modernization theory and its western bias (although some globalization theorists [e.g., Galtung 1997; Giddens 1990; Hall 1997] retain this bias). It is not surprising, therefore, that globalization theory has emerged as one of the most widely discussed and hotly debated perspectives in contemporary social theory.

Given the vast expanse of globalization theory, it would be impossible in a single essay to address the full range of perspectives that it encompasses (for a sampling, see Lechner and Boli 2000). Nevertheless, although globalization theorists differ on a number of issues, they focus primarily upon the world as a system and devote most of their attention to global processes that transcend or operate more or less autonomously from individual societies or nations.

Theories of globalization can be classified on the basis of their emphasis on cultural, economic, political, and/or institutional factors, on the one hand, and whether they stress homogeneity or heterogeneity, on the other. 
At the extremes, the globalization of culture can lead either to a trend toward common codes and practices (homogeneity) or to a situation in which many cultures interact to create a kind of pastiche or a blend leading to a variety of hybrids (heterogeneity). The trend toward homogeneity is often associated with cultural imperialism (see below). There are many varieties of cultural imperialism including associating it with American culture (Smith 1990), the West (Giddens 1990), or core countries (Hannerz 1990). Robertson (2001), although he doesn't use the term, seems to be describing a series of hybrids when he talks about the interpenetration of the universal and the particular, as well as in his discussion of the "glocal." Garcia Canclini (1995), Pieterse (1995), and others talk specifically about hybrids; Featherstone and Lash (1995), Abu-Lughod (1997), and Friedman (1994) describe a world characterized by a cultural pastiche. The pastiche may include a "global culture" (the world of jet setters and of international board rooms) that becomes yet another component of world culture.

Theorists who emphasize economic factors tend to focus on homogeneity (Harvey 1989; Piore and Sabel 1984; Wallerstein 1974). They generally see globalization as the spread of the market economy throughout the world. In a recent, more specific example, Chase-Dunn et al. (2000) have focused on the globalization of trade. While those who focus on economic issues tend to emphasize homogeneity, most acknowledge that some differentiation (heterogeneity) exists at the margins of the global economy. Other forms of heterogeneity involve, for example, the commodification of local cultures and the existence of flexible specialization that permits the tailoring of many products to the needs of various local specifications.

A political/institutional orientation, too, either emphasizes homogeneity or heterogeneity. Meyer et al. (1997), for example, focus on the nation-state, more specifically, the existence of worldwide models of the state and the emergence of isomorphic forms of governance. Keohane and Nye (1989) focus on the global influence of a multiplicity of institutions. Hobsbawm (1997) and Appadurai (1996) see transnational institutions and organizations greatly diminishing the power of both the nation-state and other, more local social structures to make a difference in people's lives. This is the phenomenon that Barber (1995) has termed "McWorld," the antithesis of which is "Jihad"-localized, ethnic, and reactionary political forces (including "rogue states") that involve an intensification of nationalism and lead to greater heterogeneity (Barber 1995; also Appadurai 1996).

Given the great scope of globalization theory, and the rate at which the literature is growing, we will not be able to address it in anything approaching its entirety in this essay. To make this discussion manageable we will focus on a recent statement by one of its foremost practitioners, Roland Robertson. Robertson is associated with the cultural approach to globalization and while he reaffirms that position in the essay, "Globalization Theory 2000+," (2001), he also seeks 
to deal with the significance of economic and political/institutional factors. In this context he seeks to identify and discuss the key problems in globalization theory. In this essay we will examine several of Robertson's ideas from the point of view of related processes that Ritzer (1998, 2000; Smart 1999; Alfino, Caputo and Wynyard 1998) has termed "McDonaldization" and the emergence of the "New Means of Consumption" (Ritzer 1999). This will allow us to analyze some of the strengths and weaknesses of globalization theory, at least as Robertson presents it.

While an important development, globalization theory is often presented as a series of broad generalizations that are not embedded in specific details of the social world. One of the things that the study of McDonaldization and the New Means of Consumption allows us to do is to examine some of the premises and assertions of globalization theory within the context of a specific set of developments about which much is known. It allows us to "test," at least in a very rough sense, some of the basic tenets of globalization theory. We will see that while globalization theory has much to offer to our understanding of McDonaldization and the New Means of Consumption, the specifics of these processes make it clear that some of globalization theory's basic tenets need to be both tempered and made far more specific.

\section{A Brief Introduction to McDonaldization and the New Means of Consumption}

Before proceeding to a discussion of the relationship between globalization, McDonaldization, and the New Means of Consumption, we need a brief introduction to the latter two (to parallel the brief sketch of globalization theory offered above) in order to orient the ensuing discussion.

McDonaldization. This is the process by which the principles of the highly successful and revolutionary fast food restaurant are coming to dominate more and more sectors of American society and an increasing number of other societies throughout the world. The principles of the process are efficiency, calculability, predictability, and control, particularly through the substitution of nonhuman for human technology; also associated with McDonaldization are the seemingly inevitable irrationalities of rationality. The basic concept, as well as its fundamental dimensions, is derived from the German social theorist Max Weber's (1921/1968) work on formal rationality. Weber contended that the modern Western world was characterized by an increasing tendency towards the predominance of formally rational systems. Thus, the process of McDonaldization obviously predates the establishment and proliferation of McDonald's restaurants (Weber 1927/1981). However, the McDonald's franchise system and the principles upon which it has so successfully spread throughout the world represent the exemplar (as was the bureaucracy in Weber's model) of the contemporary development of rationalization. While the fast food restaurant is the paradigm of this process, the process of McDonaldization has by now affected 
most, if not all, social structures and institutions in the United States, and has penetrated most nations (at least those that are reasonably developed economically) in the world. Thus, the term McDonaldization is not restricted to the fast food industry or to the United States. Rather, it refers to a wide-ranging and farreaching, but distinctive process, of social change.

The McDonaldization model has been applied well beyond the fast food restaurant and even everyday consumption to such disparate phenomena as higher education ("McUniversity") (Parker and Jary 1995), vegetarianism (Tester 1999), theme parks (Bryman 1995, 1999a; Ritzer and Liska 1998), southern folk art (Fine 1999), and politics (Turner 1999; Beilharz, 1999). (Bryman [1999b] has even recently proposed a process of "Disneyization" as a complement to McDonaldization.) McDonaldization is a broad social development. Even the processes surrounding birth and death increasingly conform to its principles (see Ritzer 2000, chapter 8).

Of course, not all systems are equally McDonaldized; McDonaldization is a matter of degree with some settings having been more McDonaldized than others. However, few contemporary social settings or institutions have been able to escape its influence altogether.

The relevance of the McDonaldization thesis to issues of globalization should be apparent, for, both implicitly and explicitly, it asserts that social systems in contemporary society are becoming increasingly McDonaldized and, more important, that the basic principles of efficiency, calculability, predictability, and control through the substitution of nonhuman for human technology that undergird it have been exported from the United States to much of the rest of the world. To the extent that these principles have been adopted and become defining features of institutions in other nations, they can be said to be undergoing the process of McDonaldization.

It is worth noting that when they have addressed the McDonaldization thesis and related ideas, some globalization theorists (e.g., Robertson 2001), especially those committed to the idea of heterogeneity, have tended to be critical of McDonaldization's focus on processes emanating from the United States and for its emphasis on its homogenizing impact on much of the rest of the world. Instead, they focus on diversity, the multi-directionality of global flows and the existence of global processes that are relatively autonomous of specific nation-states. While all of these processes exist and are significant, it is also the case that some aspects of globalization are best described as flowing from the United States and having a largely homogenizing effect on much of the rest of the world. We will return to the relationship between McDonaldization and globalization at a number of points in the ensuing discussion.

The thesis that the United States is undergoing a process of McDonaldization and that it is actively exporting manifestations of that process to much of the rest of the world is obviously a global perspective, but it is both less than and more than globalization theory. On the one hand, McDonaldization does not involve anything approaching the full range of global processes. For example, many of 
the economic, political, and institutional aspects of globalization are largely unrelated to McDonaldization. On the other hand, McDonaldization involves much more than an analysis of its global impact. For example, much of it involves the manifold transformations taking place within the United States, the source and still the center of this process. Thus, McDonaldization is not coterminous with globalization, nor is it solely a global process. Nonetheless, McDonaldization has global implications and can thus be a useful lens through which to examine globalization theory, or at least some of Robertson's perspectives on it.

The New Means of Consumption. There has been an almost dizzying creation and proliferation of settings that allow, encourage, and even compel us to consume innumerable goods and services. These settings, the New Means of Consumption, have come into existence, or taken revolutionary new forms, in the United States since the close of World War II. Building upon, but going beyond, earlier settings, they have dramatically transformed the nature of consumption.

The following are the major New Means of Consumption with notable examples and the years in which they began operations:

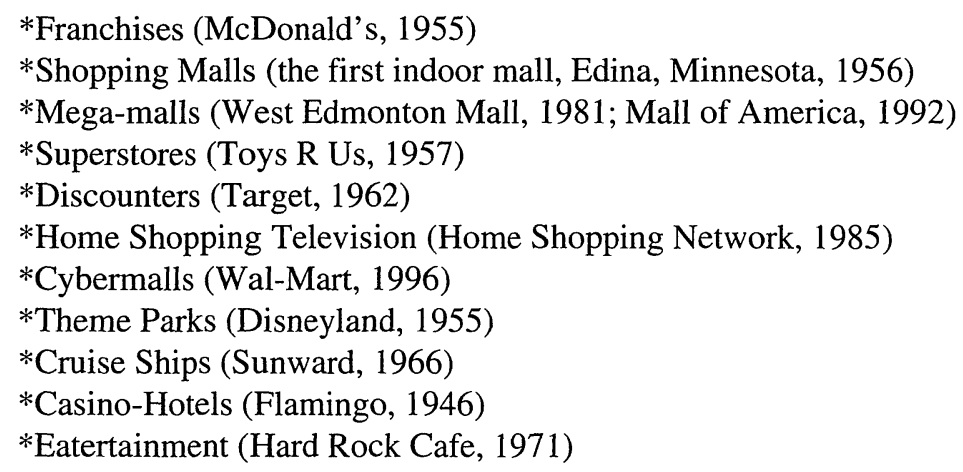

With the exception of mega-malls and the Edmonton Mall (created in Canada, but now supplanted by Mall of America as the leader in this area) and eatertainment and the Hard Rock Cafe (which was created in London, albeit to bring "American" food to England), all of these are American innovations that, in recent years, have been aggressively exported to the rest of the world; that is, they have become global phenomena.

Although all of the New Means of Consumption are highly McDonaldized (and McDonald's, fast food restaurants, and franchises are such new means) that is, the underlying principles that we've enumerated above are essential to their operations-there is much more to these settings than simply their McDonaldized characteristics. The exportation of these New Means of Consumption must be considered, along with McDonaldization, in the context of a discussion of globalization.

The development and growth of the New Means of Consumption in the United States and their exportation to much of the rest of the world is also a global 
process. However, like McDonaldization (and for many of the same reasons) the exportation of the New Means of Consumption is, at once, more than and less than globalization, and it, too, offers an important perspective through which to view globalization theory.

With this background, we will address the issue of the relationship between globalization, McDonaldization, and the New Means of Consumption. To explore this relationship we will adopt as a framework, at least in part, some of the issues raised by Robertson (2001) about globalization: First, what are the driving forces of, and most important factors in, globalization? Second, what are the relationships between the global and the local and between homogeneity and heterogeneity? Third, does globalization imply the decline of the nation-state? Finally, is there any evidence of local and international resistance to globalization?

\section{Key Factors in Globalization}

Robertson is often accused by other globalization theorists of underestimating the importance of economic factors as driving forces in globalization. $\mathrm{He}$ acknowledges this and admits to downplaying their significance. While he continues to adhere to a view that emphasizes cultural factors, he concludes that globalization has no single motor force; such forces (politics is a third factor) will vary from one historical situation to another and must be studied empirically. Thus, the question of the relative importance of motor forces can only be answered empirically in cases like McDonaldization and the exportation of the New Means of Consumption.

The interaction of culture and economics is obviously central to the origins of McDonaldization. While Ritzer, like Robertson, emphasizes the importance of cultural factors (e.g., the fit between a culture that values efficiency and acceptance of McDonaldized systems), in the end he concludes that material - that is, economic - factors (especially profitability within a global capitalistic market) are the motor forces behind the spread of McDonaldization. Since McDonaldization involves a far more specific set of processes than globalization, it is possible to identify its driving force more precisely. For example, if we look at the paradigm for the process-the McDonald's restaurant-it is clear that no given restaurant, nor the entire chain itself, would exist were it not for the search for profits and that these enterprises are, and continue to be, profitable.

The spread of the McDonald's chain throughout the world represents the kind of specific empirical case suggested by Robertson. That is, it is an instance where one can study in historical detail the forces that caused, and continue to cause, the international expansion of the chain and assess the relative weight of economic, cultural, political (and other) factors. Robertson suggests the importance of comparative empirical research, and one could even do such a study comparing the origins of McDonald's to those of other chains that developed in the United States, or to chains that have emerged more recently in many other nations. One point to be made about the latter is that McDonald's itself has 
become a motor force in the rise of those chains. That is, it is the success of McDonald's, and the methods by which it achieved that success, that have facilitated the development of indigenous chains.

Perhaps the most important point, however, is that, just as Robertson views his work on globalization as part of the "cultural turn," the work on McDonaldization is of much the same genre. That is, even if economics is the motor force behind McDonald's, the process of McDonaldization is much more important culturally than it is economically (although, as Robertson points out, the two are increasingly difficult to distinguish from one another-the economic is becoming cultural, the cultural economic); the process of McDonaldization is transforming not only the culture of the United States, but also those of much of the rest of the world.

The most notable and more directly visible cultural impact is the way McDonald's is altering the manner in which much of the rest of the world eats. What and how people eat is a crucial component of almost all, if not all, cultures, but with the spread of the principles of McDonaldization virtually everyone in McDonaldized societies is devouring french fries (and virtually every other kind of food) and doing so quickly, often on the run (we will discuss some exceptions to this below). Of course, not just food, but many other sectors of many societies (health care, politics) are being McDonaldized and as a result the cultures of those societies, the way people live many aspects of their lives, are being transformed.

Much the same thing could be said about the New Means of Consumption. Each one of them, as well as the New Means of Consumption taken collectively, offers the possibility of an empirical test of the relationship between cultural, economic, political (and others) factors. The motor force is once again clearly economic-New Means of Consumption would not be created or survive were they not successful economically, and they would not be exported internationally were they not economically rewarding to the largely American corporations of which they are part. Yet, what is critical about all of the New Means of Consumption is that they are powerful representations of American culture and they all bring that culture to any nation to which they are exported. A good example is Disney World, which has been exported to Japan and France with other foreign ventures planned or in the discussion stage. On the one hand, Disney World is clearly a product of American culture, or at least Walt Disney's romanticized "Main Street" vision of that culture circa 1900. On the other, it brings American culture and some of its most famous icons (Mickey Mouse, Donald Duck) to those areas of the world to which it has been exported. Like most of the other New Means of Consumption (and McDonaldization), Disney has been welcomed by many in other countries, but its establishment abroad has also elicited extremely negative responses from critics concerned about its impact on national cultures. For example, at the opening of Euro Disney, a French politician said that it will "bombard France with uprooted creations that are to culture what fast food is to gastronomy" (Riding 1992, A10). 
Both McDonaldization and the export of the New Means of Consumption tend to support Robertson's emphasis on cultural factors in the process of globalization. However, it is clear that neither process would have been begun without the expectation of economic rewards and both continue because they are enormously profitable. Nevertheless, the specifics of such case studies illustrate that there are other forces involved such (as McDonald's own success) as important factors in the international spread of McDonaldization. Much the same could be said for many of the other New Means of Consumption. For example, Disney is a similarly important international icon and its success has led to the creation of clones of its various enterprises throughout the world.

\section{The Relationship between the Global/Local and Heterogeneity/Homogeneity}

The relationship between global/local and heterogeneity/homogeneity is an area where there are fairly substantial differences between McDonaldization and the exportation of the New Means of Consumption and globalization, although they are mainly matters of emphasis. Robertson (2001) is at pains to argue that "globalization is not an all-encompassing process of homogenization but a complex mixture of homogenization and heterogenization." Featherstone (1990, 2) writes of global culture "in terms of the diversity, variety and richness of popular and local discourses, codes and practices which resist and play-back systemicity and order." Far from giving us a universally homogenous culture, globalization defines a space in which the world's cultures rub elbows and generate new, heterogeneous meanings and understandings. Featherstone and Lash $(1995,2)$ delineate a world in which "international social, political and cultural (for example the media) organizations are standing alongside and beginning to replace their national counterparts." They see every national culture in the mix, so that it is possible to discuss Americanization, Europeanization, Japanization - and even Brazilianization. Of more direct relevance to this discussion, Robertson (2001) argues: "the frequent talk about the McDonaldization of the world has to be strongly tempered by what is increasingly known about the ways in which such products or services are actually the basis for localization," and he cites approvingly James L. Watson's (1997) Golden Arches East: McDonald's in East Asia. Given its centrality to Robertson's argument, and to the larger issue of homogeneity/heterogeneity, Watson's book, a series of essays on the impact of McDonald's on a number of Asian cities, represents an appropriate place to view the relationship between globalization and McDonaldization and the New Means of Consumption. Watson $(1997,6)$ contends that "East Asian consumers have quietly, and in some cases stubbornly, transformed their neighborhood McDonald's into local institutions." McDonald's adapts to each distinctive cultural context and, as a result, is so modified that it is ultimately impossible to distinguish the local from the foreign. Thus, in China McDonald's is seen as much a Chinese phenomenon as it is an American phenomenon. In Japan, 
McDonald's is perceived by some as "Americana as constructed by the Japanese" (Ohnuki-Tierney 1997, 173). In Watson's terms, it is a "transnational" phenomenon. Rather than being monolithic, McDonald's, in Watson's view, is a "federation of semi-autonomous enterprises." We begin with the evidence in support of this position (heterogeneity) and then turn to a discussion of the alternative view that McDonaldization is an imperialistic force (homogeneity).

McDonald's as a Local Phenomenon. There is no question that McDonald's (and other McDonaldized systems) adapt to local conditions, realities, and tastes. In fact, the president of McDonald's International says that the goal of the company is to "become as much a part of the local culture as possible" (Sullivan $1995,1)$. Thus, while its basic menu remains intact, McDonald's has added local foods in many nations.

Even more adaptive in terms of foods are the smaller American food franchisers (Big Boy, Dairy Queen, Schlotzky's Delicatessen, Chesapeake Bagel) that have followed McDonald's and the other American giants overseas. In 1998, alone, these mini-chains opened 800 new restaurants overseas and as of that year there were more than 12,000 of them in existence around the world (Frank 2000). However, such mini-chains are far weaker than McDonald's and therefore must be even more responsive to local culture. Thus, Big Boy sells things like "country-style fried rice and pork omelette" and has added sugar and chile powder to make its burgers more palatable to its Thai customers. Because it caters to many European tourists, it has added Germanic foods like spatzle to its menu. Said the head franchiser for Big Boy in Thailand: "We thought we were bringing American food to the masses. . . . But now we're bringing Thai and European food to the tourists. It's strange, but you know what? It's working" (Frank 2000, B4).

McDonald's (as well as the mini-chains) also adapts to the local environment in the way it operates its outlets. In Beijing, the menu is identical to that in America, but the food is eaten more as a snack than as a meal. In spite of perceiving the food as a snack, Beijing customers (and those in other nations, as well) often linger for hours rather than eating quickly and leaving or taking their food with them as they depart the drive-through window, which undermines one of the principal dimensions of McDonaldization-efficiency. Perhaps the biggest difference, however, is that in Beijing McDonald's seeks to be more human by consciously presenting itself as a local company, as a place in which to "hang out" and celebrate important events and ceremonies (e.g., children's birthday parties) rather than simply a place to get in to and out of as quickly as possible. Personal interaction is emphasized by employing five to ten female receptionists, who are referred to as "Aunt McDonalds" (similarly, Ronald McDonald is known as "Uncle McDonald" in Taiwan), whose main tasks involve dealing with children and talking to parents.

Instead of discouraging the lingering of children, McDonald's in Hong Kong (and Taipei) tends to encourage it, especially for children on their way home from 
school. As in Beijing, McDonald's in Hong Kong is a more personalized setting where customers take about twice as much time as Americans to eat their food. It is a teenage hangout from three to six in the afternoon, and McDonald's makes no effort to limit table time. Overall, McDonald's feels more like "home."

Also in Hong Kong, McDonald's employees rarely smile at customers, but instead display the traits valued in that culture- - competence, directness, and unflappability" (Watson 1997a, 91). Those who eat in Hong Kong's McDonald's do not bus their own debris. In addition, napkins are dispensed one at a time because if they were placed in a public dispenser, they would disappear quickly. In Taipei, McDonald's is also a hangout for teenagers and more generally is treated as a home away from home; it is "familiar and indigenous" (Wu 1997, 125). The same customers return over and over and come to know one another and the employees quite well.

Although there is considerable evidence that McDonald's (and other McDonaldized systems) adapts, and this adaptation has helped it to succeed overseas, an important question is whether this adaptation constitutes a threat to McDonald's because it goes against the very basis of the success of the systemits standardized foods and methods of operation (Barboza 1999). That is, if McDonald's adapts too much, "goes native," and loses its identity and uniformity, will it undermine the very source of its worldwide success? If local McDonald's around the world go their own way, will they eventually cease to be identifiable as McDonald's? Will the company itself (or at least its international operations) eventually be undermined, and perhaps destroyed, by such local adaptation? Moreover, will its surrender to these local practices that obviously undermine the efficiency that it achieves in the United States make it economically unprofitable?

McDonald's as Cultural Imperialism. In contrast to those who emphasize the local adaptation of American imports, others argue that McDonaldized systems are imposing themselves on local markets in other societies and in the process transforming local economies and cultures. The enormous expansion of such systems in the international arena is one indication of this cultural imperialism. Second, while McDonald's may adapt to local realities in terms of the food and the way it runs its operations, the fact remains that not only the basic menu, but also-and more important - the fundamental operating procedures remain essentially the same everywhere in the world. Third, in many ways, it is not the existence of American chains (and other New Means of Consumption) in other countries that is the most important indicator of the spread of McDonaldization, but rather the existence of indigenous clones of those McDonaldized enterprises. After all, the importation of American products in other countries could simply be a manifestation of an invasion of isolated and superficial elements that represent no real and fundamental threat to the underlying realities of those countries. However, it is clear that the emergence of local variations on American consumption mechanisms reflects an underlying change- the McDonaldization of those societies. 
The power of McDonald's to transform local restaurants is evident in Moscow. The initial success there of McDonald's restaurants, which were greeted with great fanfare and long lines (Ingwerson 1997, 1), led to the development of many imitators, indigenous enterprises such as Russkoye Bistro that now has over 100 outlets and serves 35,000 to 40,000 customers per day. Said Russkoye Bistro's deputy director, "'If McDonald's had not come to our country, then we probably wouldn't be here"' (Hockstader 1995, A13). Further, "we need to create fast food here that fits our lifestyle and traditions.... We see McDonald's like an older brother. ... We have a lot to learn from them' " (Hockstader 1995, A13). That is the central point: innumerable institutions throughout the world feel that there is much to learn from McDonald's and what is critical are the basic principles that the process of McDonaldization embodies.

In China, local restaurants copied the McDonaldized imports. For example, Ronghua Chicken and Xiangfei Roast Chicken emulated Kentucky Fried Chicken. The Beijing Fast Food Company has almost a thousand local restaurants and street stalls that sell local fare. Several of the company's executives are former employees of KFC or McDonald's where they learned basic management techniques. They are applying the methods of those McDonaldized systems to the preparation and sale of local cuisine. Government officials and those from the restaurant and catering businesses often tour McDonald's restaurants. Even "the most famous restaurant in Beijing-Quanjude Roast Duck Restaurant—sent its management staff to McDonald's in 1993 and then introduced its own 'roast duck fast food' in early 1994" (Yan 1997, 75).

In Japan, the strongest competitor to McDonald's is Mos Burger (with 1,500 outlets) which serves "a sloppy-joe-style concoction of meat and chile sauce on a bun" (Ohnuki-Tierney 1997, 165). In Taipei, local establishments have become "fast food-style restaurants" (Wu 1997). In Seoul, competitors to McDonald's include Americana and Uncle Joe's Hamburger (the inventor of the kimchi burger featuring an important local condiment-spicy pickled cabbage).

However, the impact of McDonaldization is much more pronounced than minor changes in the operations of local restaurants alone; indeed, McDonaldization is likely to lead to changes in the customs of society as a whole. In Korea (and Japan) the individualism of a meal at McDonald's threatens the commensality of eating rice that is cooked in a common pot and of sharing side dishes. As in the United States, McDonald's in Hong Kong has helped to transform children into customers. Immigrants to the city are given a tour that ends at McDonald's! The clear implication is that this is very best Hong Kong has to offer. In Japan, McDonald's is described as a new "local" phenomenon. One of the pieces of evidence for that is that a Japanese Boy Scout was surprised to find a McDonald's in Chicago; he thought it was a Japanese firm.

From our perspective these cultural transformations, like the development of indigenous McDonaldized settings, exemplify the power of McDonaldization. Its impact is far greater if it infiltrates a local culture and becomes a part of it than if 
it remains perceived as an American phenomenon superimposed on a local setting. As local residents come to see McDonaldized systems as their own, it seems certain that the process of McDonaldization will continue to expand and embed itself ever more deeply into the cultures and everyday realities of societies throughout the world.

This discussion of cultural transformation points to another important difference with the position taken by Robertson and other globalization theorists. In rejecting the idea of cultural imperialism and McDonaldization, Robertson argues that globally few goods and services are standardized. While this may be true, of far greater importance are the standardized principles by which McDonaldized systems, both global and local, operate. Thus, it is far less significant that in Russkoye Bistro blinis rather than hamburgers are sold than that the cooking, serving, and sale of both is based on a very similar set of standardized principles.

Consider Yan's conclusion to an essay on McDonald's in Beijing: "It is . . . tempting to predict that, twenty years from now, the 'American' associations that McDonald's carries today will become but dim memories for older residents. A new generation of Beijing consumers may treat the Big Mac, fries, and shakes simply as local products" (Yan 1997, 76). The author takes this to mean that the local will triumph over McDonaldization, Americanization, and globalization, but to us it represents the strongest possible evidence of the triumph of all three over the local.

Ohnuki-Tierney (1997) seems to take consolation that McDonald's has not really altered Japanese dinners or even lunches, and this is true elsewhere in Asia, as well. As we have seen, McDonald's food is viewed there more as snack food than as meal. Yet Ohnuki-Tierney also recognizes that something of great cultural importance-the way people eat- $i s$ being altered. For example, the traditional Japanese taboo against eating while standing has been undermined by the fast food restaurant (the valuable real estate in Japan necessitates standing; in the United States larger restaurants that permit more seating can be built comparatively inexpensively). Also subverted to some degree is the cultural sanction against drinking directly from a can or bottle. She claims that the norm against eating with one's hands is holding up better (the Japanese typically eat their burgers in the wrappers so that their hands do not touch the food directly). Nevertheless, that deeply held norms are being transformed by McDonald's is evidence of the profound impact of McDonaldization.

While those who accept the cultural imperialism argument tend to emphasize the negative effects of McDonaldization on local customs, we must not forget that the imperialism of McDonaldized systems brings with it many advances over local ways of doing things. For example, in both Hong Kong and Taipei McDonald's virtually invented restaurant cleanliness and served as a catalyst for improving sanitary conditions at many other restaurants in the city.

While we argue in favor of the cultural imperialism position, at least in the case of McDonaldization, it is impossible to offer a single generalization that 
applies equally well to all nations. For example, in Korea, unlike other East Asian locales, there is a long history of anti-Americanism (co-existing with proAmerican feelings), and there is great fear among Koreans of encroaching Americanism and the loss of Korean identity. Thus, one would anticipate greater opposition there to McDonaldization than in most other nations.

Finally, while a general threat to indigenous culture exists, there are counterexamples that demonstrate that McDonaldization has instead contributed to the revitalization of local traditions. For example, while fast food restaurants have boomed in Taipei, they have helped lead to the revival of indigenous food traditions such as the eating of betel nuts. More generally, in his book, Jihad vs. McWorld, Benjamin Barber (1995; see also, Friedman 1999) argues that the spread of "McWorld" brings with it the development of local fundamentalist movements ("Jihads") deeply opposed to McDonaldization. ${ }^{1}$

The New Means of Consumption, Localism, and Imperialism. Many of the same points apply to the New Means of Consumption more generally. For example, many have adapted to local cultures by altering what they sell and how they sell it. While many of the New Means of Consumption succeeded in entrenching themselves in many other countries, they have also given rise to indigenous versions that have adopted most of their underlying principles and methods of operations. Thus, for example, Europe has its own superstores that represent serious competition to the successful exportation of Wal-Mart and Costco. European television carries its own varieties of televised home shopping, obviously influenced by the American innovators in this area. American e-tailers and cybermalls are available throughout the world, but so are local clones of both. From our perspective, it makes little difference whether people utilize Americanbased or indigenous versions of superstores, home shopping networks, or etailers. While indigenous versions may manifest a variety of inputs, by far the most powerful are those that emanate from the American pioneers and leaders in this area.

Take the case of Latin America's Rock in Rio Cafe. Its developers are very cognizant of American theme restaurants (eatertainment) and have made it clear that they have taken the lead from them in creating a spectacular chain of restaurants that include entry via monorail, changing projected imagery on the walls, and indoor fireworks (Friedland 1997). While Rock in Rio has its local touches, it is clearly heavily influenced by American theme restaurants. Its spread throughout Latin America may be expedited by those local touches and local ownership, but it is still bringing with it a very American approach to restaurants and eating with little emphasis on the nature and quality of the food and much on the spectacular nature of the setting. In some sense it matters little whether those in Rio de Janeiro eat in Rock in Rio or in Planet Hollywood since both are New Means of Consumption. But, in another sense, the seemingly local character of the former obscures its American roots and therefore poses an even greater threat to indigenous culture. 
The more general point is that the American pattern of consumption-what may be termed "hyperconsumption,"-accompanies and undergirds both the exportation of the New Means of Consumption and the opening of indigenous versions of these American imports. These settings encourage people around the world not only to consume more, but also to consume more like Americans. That is, more and more people engage in mass consumption, spend most if not all of their available resources on consumption, and increasingly go into debt in order to support such a consumption pattern.

It is not just how much people consume that is being changed; it is also the ways in which people consume. Instead of paying cash for the things they consume, increasingly large numbers of people around the world follow large numbers of Americans into debt by using credit cards. The credit card (a mechanism that facilitates the use of the New Means of Consumption rather than itself being such a new means), which had its origins and still has its base in the United States, is also an American export (Ritzer 1995). Instead of the traditional method of shopping at a variety of local shops and stands, people around the world are increasingly embracing the American pattern of one-stop shopping at supermarkets, hypermarkets, superstores, and shopping malls. Instead of visiting shops where clerks and shopkeepers perform various tasks for consumers, people are increasingly following the American pattern of doing more and more things relating to consumption for themselves. Perhaps most important, the American pattern of making consumption less social is being adopted throughout the world. For example, instead of interacting with familiar shopkeepers on a regular basis, many are doing things for themselves in vast stores and malls, interacting only briefly and anonymously with robot-like clerks, or, in the most extreme case, interacting with nothing more than television and computer screens. Whether or not they consume in American-based means of consumption, others around the world are increasingly consuming like Americans. As with the case of McDonaldization, there is great variation in this from one locale to another, and the success of the New Means of Consumption is likely to lead to local counterreactions and perhaps even to a revival of traditional consumption settings. Nevertheless, it seems safe to say that the exportation of the New Means of Consumption, and the development of indigenous copies of these settings, are leading to a worldwide movement in the direction of American-style patterns of consumption. Thus, the cases of the exportation of the New Means of Consumption and McDonaldization point much more to cultural imperialism and homogeneity than they do to localism and heterogeneity. ${ }^{2}$

\section{Globalization and the Nation-State}

Robertson (2001) contends that, as a consequence of globalization, "the nation-state is being simultaneously weakened and strengthened." From the broad perspective of globalization theory, this is certainly accurate. However, when looked at through the lens of McDonaldization and the exportation of the 
New Means of Consumption, at least at this point in their historical development, two points are clear. First, both of these processes operate transnationally with little interference from the state. Such transnational flows serve, at least to some degree, to undermine the power of the state. For example, for obvious reasons the Chinese government (to take one example) may want to keep McDonald's or other New Means of Consumption out, but the public demand for them has made that impossible. By allowing McDonaldized systems based in the United States (and elsewhere) in, China is both admitting its weakness and further increasing that weakness. Chinese citizens and observers around the world see the inability of the Chinese to resist McDonaldization and they strive to further exploit that weakness. This is even clearer in the case of the Internet and the cybermalls and e-tailers that are such an increasing presence on it. Unable to keep the Internet out, the Chinese are therefore unable to keep out these New Means of Consumption and the types of consumption and consumer goods associated with them.

Second, while overall McDonaldization and the New Means of Consumption suggest the weakness of the state, they indicate again, at least in this point in history, the power of a single state-the United States. McDonald's, the process of McDonaldization it helped spawn, and the New Means of Consumption are distinctive products of American society, and their spread throughout the world enhances the global reach and power of the United States. Furthermore, a significant portion of the profits earned abroad return to American shores, and some find their way into the American treasury. However, while McDonaldization and the exportation of the New Means of Consumption work to the interests of the American state, it is also the case that the corporations involved in these processes operate largely independently of the U.S. government. In that sense, they can be said to undermine the power of the American state and the nation-state in general.

Thus, the study of McDonaldization and the New Means of Consumption points to the growing power of the corporation over the nation-state in the globalization process. Corporations have long operated at least semi-autonomously and to the detriment of state power, but this seems to be reaching new heights in contemporary corporations, especially those involved with McDonaldized systems and the New Means of Consumption. Increasingly, the corporation, not the state (even the American state), has become the most important actor on the world stage and the gap between these two entities is likely to grow in the future. This reality is captured in an anecdote that Friedman reports about a former U.S. ambassador to Israel who officiated at the opening of the first McDonald's in Jerusalem while wearing a baseball hat with the McDonald's golden arches logo:

An Israeli teen-ager walked up to him, carrying his own McDonald's hat, which he handed to Ambassador Indyk with a pen and asked: "Are you the Ambassador? Can I have your 
autograph?" Somewhat sheepishly, Ambassador Indyk replied: "Sure. I've never been asked for my autograph before."

As the Ambassador prepared to sign his name, the Israeli teen-ager said to him, "Wow, what's it like to be the ambassador from McDonald's, going around the world opening McDonald's restaurants everywhere?"

Ambassador Indyk looked at the Israeli youth and said, "No, no. I'm the American ambassador-not the ambassador from McDonald's!" Ambassador Indyk described what happened next: "I said to him, 'Does this mean you don't want my autograph?' And the kid said, 'No, I don't want your autograph,' and he took his hat back and walked away." (Friedman 1999, 43-44)

Such actions challenge Robertson's (2001) assertion that "the nation-state remains the central and most formidable actor in world affairs generally."

On the other hand, the perspective that we are arguing is also at odds, at least in part, with the view of some globalization theorists, most notably Appadurai (1996), that what is most significant about globalization is the existence of global processes that operate independently of, and free of ties with, any given nation. While our previous discussion of the independence of corporations tends to support such a stance, the overall thrust of this essay is to stress the persistence of ties to the United States and American culture. Thus, while it is undeniable that there are global processes that operate free of any nation-state, one nation-state remains disproportionately important in globalization. The nation-state may, as Robertson suggests, not be as formidable as it once was, but, at least in the realms being discussed here, the United States remains a powerful presence.

\section{Local and Global Resistance}

One of the issues highlighted by the specifics of McDonaldization and the exportation of the New Means of Consumption is the nature of the resistance to them. Robertson discusses such resistance in terms of anti-global movements that themselves involve globalization. Once again, the specific issues of concern here allow us to examine the nature of this resistance much more concretely.

The global reach of McDonaldization and the exportation of the New Means of Consumption have given rise to reactions against these processes that are similarly transnational. For example, the exportation of McDonald's led to the infamous McLibel trial in Great Britain ${ }^{3}$ and more important to a global McLibel movement against McDonald's franchises, as well as many other New Means of Consumption (Vidal 1997). Several million copies of the leaflet that led to the trial, "What's Wrong With McDonald's: Everything They Didn't Want You to Know," have been distributed around the world and it has been translated into a number of languages. More important, a website dedicated to opposing McDonald's 
and related phenomena (http://www.mcspotlight.org/), has reported an average of 1.75 million "hits" a month, a total of 65 million hits by March 1999. It acts as the repository for information on actions taken against local McDonald's throughout the world. It has become the heart of a worldwide movement in opposition to McDonald's, as well as other aspects of our McDonaldized world. For example, in one month it reported efforts to block the opening of new McDonald's restaurants in Surrey, England; Kerikeri, New Zealand; Torquay, Australia; and Edmonton, Canada. Among "McSpotlight's" other targets is the Body Shop, which is accused of using its "green" image to conceal that its products are detrimental to the environment, that it pays low wages, and that it encourages consumerism.

Another reaction against McDonaldization has been The Slow Food movement, which was initiated in the mid-1980s by an Italian food critic against the opening of a McDonald's in Rome. It is opposed to the homogenization of food styles and takes as its mission "to give voice to local cooking styles and small-time food producers." In addition to its anti-McDonald's stance, more recently it has taken on "fending off the homogenizing effects of European Union regulations on regional culinary treasures" (Richman 1998, M1). Its objective "to provide members from all different countries with an identity and [to propagate] convivia throughout the world" (Slow, 1998) reflects its anti-McDonaldization animus. It has over 400 chapters (called Convivia) and a membership of 40,000 people, mostly in Europe, but also in 35 other nations. Among other things, the movement has a website (www.slowfood.com), publishes a handsome journal (Slow), and held its first biennial meeting, "Salone del Gusto: World Flavours in Piedmont," in Turin, Italy, in late 1998.

This is clearly a movement of a very different order from the McLibel group. The impoverished targets of the McDonald's libel suit are a far cry from the mainly well-heeled gourmets drawn to Slow Food. The Slow Food movement focuses on the issue of the poor quality of food (and, implicitly, almost all other products) in McDonaldized restaurants and food emporia, while McLibel focuses on threats to health (as does another movement, National Heart Savers), the environment, and workers. While there are differences in goals, methods, and in the social class backgrounds of most of the participants, these two groups share hostility to the McDonaldization of society (and the New Means of Consumption), and they are global in their reach.

Turning to otherNew Means of Consumption, Sprawl-Busters (info@ sprawlbusters.com), founded by Al Norman, grew out of his successful effort to keep Wal-Mart out of his hometown, Greenfield, Masachusetts. Now the organization offers consulting services to local communities that want to keep McDonaldized superstores and chains out. For his efforts, the TV program "60 Minutes" called Norman "the guru of the anti-Wal-Mart movement." Among the services offered by the organization to local communities is help with overseeing media operations, raising money, referenda, data searches, and the like. Beyond Wal-Mart, 
organizations on Sprawl-Buster's "hit list" include Super Kmart, Home Depot, CVS, and Rite-Aid. The main objective is to keep out such superstores and chains - prime examples of the New Means of Consumption—in order to protect local businesses and the integrity of the local community.

Thus, this analysis suggests that while McDonaldization and the exportation of the New Means of Consumption are global in reach, they generate opposition movements that are similarly global. It is unlikely that these opposition movements will defeat the American-based forces that they oppose, but they are likely to force them to ameliorate their worst excesses.

Although there is general accord between Robertson and the perspective offered here on global nature of resistance, one key difference is that while he sees the United States as the "home of opposition and resistance to globalization," movements such as McLibel based in England and Slow Food in Italy indicate that in the specific case of McDonaldization opposition has emerged outside of the United States as well.

However, in our rush to focus on global opposition to these global changes, we must not lose sight of the wide variety of local and individual opposition efforts (although, as Robertson points out, these cannot be clearly separated from global processes) both within the United States and throughout the world. Thus, towns as widespread as Sanibel Island in Florida and Hove in England have succeeded in keeping out McDonaldized chains. Other towns and cities throughout the world have forced such chain restaurants to mute their structures and alter their menus. Beyond the local, there is individual opposition which can take such forms as refusing to patronize McDonaldized settings and New Means of Consumption, fleeing to areas free of such settings, or even escaping into a fantasy world free of these systems.

Thus, there are many ways to oppose the forces of McDonaldization and the New Means of Consumption. A discussion of these techniques highlights the global nature of some of them, but such a global perspective might lead us to ignore other more local and individual efforts. As is true of globalization in general, a focus on specific forms of opposition reveals much more than airy generalizations about this opposition. There is much more to the changing nature of the world than is caught by globalization theory and even by the globalization process.

\section{Conclusion}

Our objective in this essay has been to examine several of the basic tenets of globalization theory from the perspective of the processes of McDonaldization and the exportation of the New Means of Consumption. Our most general point is that while there is a role for broad generalizations about the nature and consequences of globalization, they need to be closely examined in case studies that focus on specific aspects of that process. Globalization has innumerable strands and interrelated developments; we have only been able to focus on two of 
them here. However, even the examination of these two processes has made it clear that generalizations about globalization need to be tempered and specified. What is true about some aspects of globalization is not necessarily true of other aspects of that process.

This essay has focused on four issues related to globalization theory derived, at least in part, from the recent work of one prominent globalization theorist, Roland Robertson. By looking at these issues through the lenses of McDonaldization and the New Means of Consumption, we have found some support, some lack of support, and in all cases a need for greater specificity.

First, the processes of McDonaldization and the exportation of the New Means of Consumption support Robertson's assertion that globalization is multifactorial, with economic and cultural factors being of prime importance. The evidence from these processes indicates that although they must be profitable to be undertaken and maintained, it is really their cultural character and cultural implications that are of utmost importance and significance. That is not to say that culture is the most important aspect of all elements of globalization. For example, the global financial system, and its many sub-components, are undoubtedly far more important economically than they are culturally.

Second, our greatest disagreement with Robertson is over the issue of homogeneity/heterogeneity or cultural imperialism/localism. While Robertson emphasizes heterogeneity and the coexistence of the global and the local, the cases of McDonaldization and the New Means of Consumption indicate the centrality of homogeneity, cultural imperialism, and the triumph over the local. Our evidence points much more to homogeneity than heterogeneity, even though in those cases where McDonaldization and the New Means of Consumption have been most successful in embedding themselves in indigenous cultures, elements of heterogeneity, the glocal and the local survive and may even be stimulated into reasserting themselves by the success of these imperialistic efforts. Again, however, other elements of globalization might well demonstrate the reverse. We need to look at what each of these aspects of globalization show and not be satisfied with generalizations about the process.

Third, our examination of McDonaldization and the New Means of Consumption adds nuance to Robertson's assertion that globalization simultaneously weakens and strengthens the nation-state. McDonaldization and the exportation of the New Means of Consumption serves to weaken, and to demonstrate the weakness of, the nation-state in that most are powerless to resist their incursion. However, these two processes serve to strengthen the American state through increased tax revenues generated by overseas successes and by furthering the proliferation of American culture throughout the world. Ultimately, however, these processes demonstrate the growing importance of the corporation vis-a-vis the state. It is really the corporations-the multinationals and transnational entities that lie at the base of McDonaldization and the New Means of Consumption - that benefit most from their success. These corporations operate largely on 
their own, free of state control. They are little interested in the success of their state of origin or of the other states in which they do business. In the end, distinctively American products such as McDonald's, Disney, Wal-Mart, the Gap, Amazon.com, and the like will remain based in the United States only so long as it suits their interests and bottom line to do so. When, and if, it makes more economic sense to base their operations elsewhere, or to sell out to some foreign-based conglomerate, they will do so without giving a second thought to the implications of these acts for the United States. What the cases of McDonaldization and the New Means of Consumption suggest is that it is the corporation, not the state, that is key actor on the world stage today.

Finally, the specific cases of McDonaldization and the New Means of Consumption illustrate the emergence of various types of resistance to them at the individual, local, and global levels. Theorizing about resistance to globalization at a general level is useful, but we learn a great deal more about resistance, and much else, if we look at the specific forms that they take in reaction to specific dimensions of globalization.

\section{Notes}

1. However, it is worth noting that in the end Barber concludes that McWorld will win out over Jihad; to succeed on a large scale, fundamentalist movements themselves must begin to use highly rationalized, McDonaldized systems (e.g. e-mail, the Internet, television).

2. However, we should reiterate that the realities of these cases do not contradict the idea that other global processes are producing greater heterogeneity around the world.

3. McDonald's sued two impecunious young people associated with London Greenpeace for passing out anti-McDonald's pamphlets. In what became the longest libel trial in Great Britain's history, McDonald's won on most counts, but suffered an expensive public relations disaster (Vidal, 1997).

\section{References}

Abu-Lughod, Janet. 1997. “Going Beyond the Global Babble.”In A.D. King, ed., Culture, Globalization and the World-System. Minneapolis.

Alfino, Mark, John S. Caputo and Robin Wynyard, eds. 1998. McDonaldization Revisited. Westport, Conn.

Appadurai, Arjun. 1996. Modernity at Large: Cultural Dimensions of Globalization. Minneapolis. Barber, Benjamin. 1995. Jihad vs. McWorld. New York.

Barboza, David. 1999. "Pluralism under Golden Arches." New York Times, February 12.

Beilharz, Peter. 1999. "McFascism: Reading Ritzer, Bauman and the Holocaust." In Smart, ed., Resisting McDonaldization.

Bryman, Alan. 1995. Disney and His Worlds. London. 1999a. "Theme Parks and McDonaldization." In Smart, ed., Resisting McDonaldization. 1999b, The Disneyization of Society." Sociological Review 47, February.

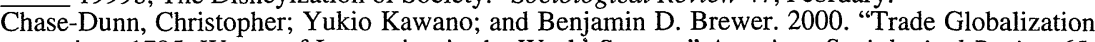
since 1795: Waves of Integration in the World-System." American Sociological Review 65, February.

Featherstone, Mike. 1990. “Introduction.” In M. Featherstone ed., Global Culture: Nationalism, Globalization and Modernity. London.

Featherstone, Mike and Scott Lash. 1995. "Globalization, Modernity and the Spatialization of Social Theory: An Introduction." In Featherstone, Lash and Robertson eds., Global Modernities.

Featherstone, Mike, Scott Lash and Roland Robertson eds. 1995. Global Modernities. London.

Fine, Gary. 1999. Art Centres: Southern Folk Art and the Splintering of a Hegemonic Market. In Smart, ed., Resisting McDonaldization.

Frank, Robert. "Big Boy's Adventures in Thailand." Wall Street Journal, April 12.

Friedland, J. 1997. "Can Yanks Export Good Times to Latins?" Wall Street Journal, March 6.

Friedman, Jonathan. 1994. Cultural Identity and the Global Process. London. 
1995. "Global System, Globalization and the Parameters of Modernity." In Featherstone, Lash and Robertson, eds., Global Modernities.

Friedman, Thomas. 1999. The Lexus and Olive Tree: Understanding Globalization. New York.

Galtung, Johan. 1997. "On the Social Costs of Modernization: Social Disintegration, Atomie/Anomie and Social Development." In Cynthia Hewitt de Alcántara, ed., Social Futures, Global Vision. Oxford, England.

Garcia Canclini, Nestor. 1995. Hybrid Cultures: Strategies for Entering and Leaving Modernity. Minneapolis.

Giddens, Anthony. 1990. The Consequences of Modernity. Stanford, Calif.

Hall, Stuart. 1997. "The Local and the Global: Globalization and Ethnicity." In A.D. King, ed., Culture, Globalization and the World-System: Contemporary Conditions for the Representation of Identity. Minneapolis.

Harvey, David. 1989. The Condition of Postmodernity: An Inquiry into the Origins of Cultural Change. Cambridge, Mass.

Hannerz, Ulf. 1990. "Cosmopolitans and Locals in World Culture." In Featherstone, ed., Global Culture: Nationalism, Globalization and Modernity. London.

Hobsbawm, Eric. 1997. “The Future of the State." In Cynthia Hewitt de Alcántara, ed., Social Futures, Global Visions. Oxford.

Hockstader, Lee. 1995. "Attack on Big Mac." Washington Post, August 8.

Ingwerson, Marshall. 1997. "That Golden Touch to the Arches in Russia." Ohio Slavic and East European Newsletter 25, Spring 1997. (Originally published in the Christian Science Monitor, 1997.)

Keohane, Robert O. and Joseph S. Nye. 1977. Power and Independence. Boston.

Lechner, Frank J. and John Boli, eds., The Globalization Reader. Malden, Mass.

Meyer, John W., John Boli, George M. Thomas, and Francisco Ramirez. 1997. "World Society and the Nation-State." American Journal of Sociology, 65, February.

Ohnuki-Tierney,Emiko. 1997. "McDonald's in Japan: Changing Manners and Etiquette," in Watson, ed., Golden Arches East.

Parker, Martin and David Jary. 1995. "The McUniversity: Organization, Management and Academic Subjectivity." Organization 2.

Pieterse, Jan N. 1995. "Globalization as Hybridization." In Featherstone, Lash and Robertson, eds. Global Modernities.

Piore, Michael and Charles Sabel. 1984. The Second Industrial Divide: Possibilities for Prosperity. New York.

Richman, Phyllis. 1998. "Savoring Lunch in the Slow Lane." Washington Post, November 22.

Riding, Alan. 1992. “Only the French Elite Scorn Mickey's Debut." New York Times, April 13.

Ritzer, George. 1995. Expressing America: A Critique of the Global Credit Card Society. Thousand Oaks, Calif.

1998. The McDonaldization Thesis. London.

1999. Enchanting a Disenchanted World: Revolutionizing the Means of Consumption. Thousand Oaks, Calif.

2000. The McDonaldization of Society: New Century Edition. Thousand Oaks, Calif. and Allan Liska. 1998. "'McDisneyization' and 'Post-Tourism"': Complementary Perspectives on Contemporary Tourism. In Chris Rojek and John Urry, eds. Touring Cultures: Transformations in Travel and Theory. London.

Robertson, Roland. 1992. Globalization: Social Theory and Global Culture. London.

1995. "Glocalization: Time-Space and Homogeneity-Heterogeneity." In Featherstone, Lash and Robertson, eds., Global Modernities. London.

2001. "Globalization Theory 2000+: Major Problematics." In George Ritzer and Barry Smart, eds., Handbook of Social Theory. London.

Slow. July-September, 1998.

Smart, Barry, ed. 1999. Resisting McDonaldization. London.

Smith, Anthony D. 1990. "Towards a Global Culture?" in Featherstone, ed. Global Culture.

Sullivan, Barbara. 1995. "McDonald's Sees India as Golden Opportunity." Chicago TribuneBusiness, April 5.

Tester, Keith. 1999. "The Moral Malaise of McDonaldization." In Smart, ed., Resisting McDonaldization.

Turner, Bryan S. 1999. "McCitizens: Risk, Coolness and Irony in Contemporary Politics." In Barry Smart, ed. Resisting McDonaldization. London.

Vidal, John. 1997. McLibel: Burger Culture on Trial. New York.

Wallerstein, Immanuel. 1974. The Modern World-System: Capitalist Agriculture and the Origins of the European World-Economy in the 16th Century. New York.

Watson, James. 1997a. "Transnationalism, Localization, and Fast Foods in Asia," in Watson, ed. Golden Arches East.

1997b. "McDonald's in Hong Kong: Consumerism, Dietary Change, and the Rise of a Children's Culture," in Watson, ed. Golden Arches East. 


\section{George Ritzer and Elizabeth L. Malone}

ed. 1997c. Golden Arches East: McDonald's in East Asia. Stanford.

Weber, Max. 1921/1968. Economy and Society. Totowa, N.J.

1927/1981. General Economic History. New Brunswick, N.J.

Wu, David Y. H. 1997. "McDonald's in Taipei: Hamburgers, Betel Nuts, and National Identity," in Watson ed. Golden Arches East.

Yan, Yunxiang. 1997. "McDonald's in Beijing: The Localization of Americana," in Watson, ed., Golden Arches East. 